\title{
Growth and Yield of Chili Pepper under Different Time Application of Wedelia (Wedelia trilobata) and Siam Weed (Chromolaena odorata) Organic Fertilizers
}

\author{
Nanik Setyowati ${ }^{\# 1}$, Zainal Muktamar ${ }^{* 2}$, Silma Oktiasa ${ }^{\# 3}$, Dwi W. Ganefianti ${ }^{\# 4}$ \\ \# Department, University of Bengkulu, Bengkulu 38371, Indonesia \\ E-mail: 'nanik_srg@yahoo.com, ${ }^{3}$ silma_oktiasa@yahoo.com, ${ }^{4}$ ganefianti_crp@yahoo.com \\ * Soil Science Department, University of Bengkulu, Bengkulu 38371, Indonesia \\ E-mail: ${ }^{2}$ muktamar1959@yahoo.com
}

\begin{abstract}
Low content of soil organic matter and low availability of nutrients in Ultisol are major constraints of this soil to support growth and development of chili pepper. Application of organic fertilizer is required to increase content of soil organic matter as well as to improve other chemical, biological, physical properties of this soil. Wedelia (Wedelia trilobata) and Siam Weed (Chromolaena odorata) are potential sources of organic fertilizer. The aim of this study was to compare growth and yield of chili pepper under different time application of Wedelia and Siam Weed based organic fertilizers. Greenhouse house experiment was conducted employing Completely Randomized Design with 2 factors namely Wedelia and Siam Weed composts as first factor and 5 (five) different time of application as second factor. Each treatment was replicated 5 times. The study showed that most variables observed in this experiment were not affected by types of compost. Only were plant height, canopy width and dry weight of biomass significant difference between the two composts. Siam weed compost applied two weeks before planting resulted in plant canopy wider than Wedelia compost. However, Wedelia compost applied at planting resulted in longer chili pepper as compared to Siam weed compost. The experiment also revealed that Wedelia compost produced higher plant height and root dry weight as compared to Siam weed compost.
\end{abstract}

Keywords - Wedelia, Siam weed, Wedelia trilobata, Chromolaena odorata, organic fertilizer

\section{INTRODUCTION}

Low fertility of Ultisol is major obstacle to support growth and development of chili pepper. Ultisol mostly has low $\mathrm{pH}$, high aluminum saturation in soil solution, low organic matter, low Cation Exchange Capacity (CEC), low availability of major nutrients as well as unfavorable soil physical properties for plant growth [1] [2]. Thereafter, microorganism activities are hampered by the characteristics of the soil. Fertility improvement of this soil is required to enable chili pepper producing good yield.

Application of manure is expected to improve the fertility of this soil. Organic matter decomposition results in increasing nutrient availability mostly N, P, K, S and others. Organic matter is also decomposed to form humic acid, fulvic acid and humin [3]. These organic acids will increase CEC of the soil and provide significant role for organicmineral interaction in $\mathrm{C}$ stabilization within micro aggregates [4]. This process will improve structure and porosity of the soil.
Study by [5] on the role of organic matter on change in selected soil chemical properties in organic farming system found out that after 4 years, soil organic C, soluble $\mathrm{P}$, exchangeable $\mathrm{K}$, and soil $\mathrm{pH}$ was higher in organic farming system than that of conventional farming system. Similar experiment conducted by [6] and [7] showed that organic farming increased soil organic $\mathrm{C}$, total nitrogen, nitrate, ammonium, Olsen-P, and Exchangeable $\mathrm{K}$ in comparison to that conventional farming.

Manure application enables to enhance the efficiency of fertilization, to improve soil quality, as well as to increase nutrient availability [8]. However, nutrient is released slowly from organic matter [9], therefore, it is crucial to find out when the organic fertilizer has to be applied to the soil. Study by [10] showed that the number of strawberry per plant and its yield significantly increased when manure was applied a week before planting as compared to that at planting date. Wedelia and Siam weed have potential as sources of organic fertilizer. Wedelia biomass has benefit as soil organic substrate to improve soil quality since it is 
mineralized quite rapidly and nutrient is readily available for plant growth [11] [12]. Other experiment shows that Wedelia biomass in soil significantly improves soil aggregates, soil porosity, organic carbon and other soil quality indicators [13] [14] [15]. Siam weed also has significant amount of biomass. Nutrient content in canopy and root biomass of Siam weed is $49.97 \%$ C-organic, $3.04 \%$ total N, $0.29 \% \mathrm{P}$, and $9.00 \%$ lignin [8]. The objective of this experiment was to compare growth and yield of chili pepper under different time application of Wedelia and Siam weed based organic fertilizers.

\section{MATERIALS AND METHODS}

\section{A. Experimental Design and Treatment}

Greenhouse experiment was conducted in Faculty of Agriculture Experiment Station, University of Bengkulu from October 2012 to March 2013, employing Completely Randomized Design (CRD) with 2 factors. The first factor consisted of Wedelia (Wedelia trilobata) compost and Siam weed (Chromolaena odorata) compost and the second factor consisted of 5 different times of compost application. Therefore, the treatment combinations were as follows:

$\mathrm{T}-1=$ Wedelia compost applied at planting date

$\mathrm{T}-2=$ Wedelia compost applied 1 week before planting date

$\mathrm{T}-3=$ Wedelia compost applied 2 weeks before planting date

$\mathrm{T}-4=$ Wedelia compost applied 3 weeks before planting date

$\mathrm{T}-5=$ Wedelia compost applied 4 weeks before planting date

$\mathrm{T}-6=$ Siam weed compost applied at planting date

T-7 = Siam weed compost applied 1 week before planting

T-8 = Siam weed compost applied 2 weeks before planting

T-9 $=$ Siam weed compost applied 3 weeks before planting

$\mathrm{T}-10=$ Siam weed compost applied 4 weeks before planting

Each treatment was replicated 5 (five) times. Data was analyzed using ANOVA at $95 \%$ confidence level. When there were significant differences, treatment mean was analyzed using Duncan's Multiple Range Test (DMRT) 5\%.

\section{B. Composting Procedure}

Weed compost was made by chopping into approximately $5 \mathrm{~cm}$ size of $50 \mathrm{~kg}$ Wedelia or Siam weed biomass. The biomass was placed in wood box and sprayed with EM-4 using Knapsack sprayer, then, was covered with transparent plastic. The mixture was maintained moist and incubated for 6 weeks. The mixture was reversed every week to maintain good oxygen supply to the mixture.

\section{Grow Media Preparation}

Soil used in this experiment was Ultisol from Kandang Limun Village, Bengkulu, Indonesia. Composite soil sample was collected from the depth of $0-25 \mathrm{~cm}$. Soil sample, then, was air dried and sieved through $5 \mathrm{~mm}$-mesh screen. Ten $\mathrm{kg}$ of soil sample in $25 \mathrm{~kg}$-polybag was mixed with Wedelia or Siam weed compost at rate of $20 \mathrm{Mg} \mathrm{ha}^{-1}$ (250 $\left.\mathrm{g} \mathrm{polybag}^{-1}\right)$. The mixture was incubated in accordance to each treatment at different times of compost application.

\section{Chili Pepper Cultivation}

The chili pepper used in this experiment was H13 strain resulting from previous experiment conducted by chili pepper breeding researchers at the University of Bengkulu. Chili seed was soaked for 24 hours before they were placed in moist paper for 3 days. After germination, shoot was transferred into seedling tray containing soil, manure and rice husk at weight ratio of $2: 1: 1$. Chili pepper seedlings were transferred into $25 \mathrm{~kg}$-polybags after 35 days and chili pepper already had 6 leaves. Each polybag was treated with Wedelia or Siam weed compost according to each treatment. No additional inorganic fertilizer was applied and compost was the only sources of N, P, K and other nutrients for chili pepper plant. During the experiment, soil in polybag was maintained moist by watering as required. Weed was controlled mechanically when necessary.

Chili pepper was harvested every 5 days when $95 \%$ of chili fruit turned red. Harvesting was completed 10 times. Variables observed in this experiment including plant height, dichotomous height, flowering time, stem diameter, canopy width, harvesting time, canopy dry weight per plant, root dry weight per plant, fruit diameter, fruit length, fresh fruit weight per plant, and weight per fruit.

\section{RESULT AND DISCSSIONS}

\section{A. Analysis of Variance}

Most of growth variables observed in this experiment are not significantly influenced either by types of compost or time of application. Plant height and canopy width of chili pepper are significantly affected by types of compost, however only are flowering time and weight per fruit significantly influenced by times of compost application. An interaction between types of compost and times of compost application is observed on canopy width and fruit length (Table 1).

\section{B. Effect of Weed Compost and Time of Application on Growth and Yield of Chili Pepper}

Table 2 shows that Wedelia compost tends to decrease canopy width when applied before planting, indicating that the application at planting is capable to provide sufficient nutrient to the plant. Canopy width of chili pepper decreases by $59 \%$ when Wedelia compost is applied 4 weeks before planting in comparison to that at planting date.

TABLE 1

ANOVA OF GROWTH AND YIELD COMPONENT VARIABLES OF CHILI PEPPER

\begin{tabular}{|l|c|c|c|}
\hline \multirow{2}{*}{\multicolumn{1}{|c|}{ Variables }} & \multicolumn{3}{|c|}{ Calculated F } \\
\cline { 2 - 4 } & $\begin{array}{c}\text { Types of } \\
\text { Compost }\end{array}$ & Times of App & Interaction \\
\hline Plant height & $6.31 *$ & $1.69 \mathrm{~ns}$ & $2.03 \mathrm{~ns}$ \\
Dichotomous height & $0.30 \mathrm{~ns}$ & $1.19 \mathrm{~ns}$ & $1.39 \mathrm{~ns}$ \\
Flowering period & $0.01 \mathrm{~ns}$ & $3.46 *$ & $2.52 \mathrm{~ns}$ \\
Stem diameter & $1.73 \mathrm{~ns}$ & $1.44 \mathrm{~ns}$ & $1.94 \mathrm{~ns}$ \\
Canopy width & $4.37 *$ & $1.10 \mathrm{~ns}$ & $3.56 *$ \\
Harvesting period & $0.81 \mathrm{~ns}$ & $1.98 \mathrm{~ns}$ & $0.81 \mathrm{~ns}$ \\
Canopy weight & $9.03 *$ & $1.04 \mathrm{~ns}$ & $1.96 \mathrm{~ns}$ \\
Root dry weight & $2.56 \mathrm{~ns}$ & $1.05 \mathrm{~ns}$ & $1.99 \mathrm{~ns}$ \\
Fruit diameter & $0.28 \mathrm{~ns}$ & $0.02 \mathrm{~ns}$ & $1.96 \mathrm{~ns}$ \\
Fruit length & $2.47 \mathrm{~ns}$ & $2.07 \mathrm{~ns}$ & $3.09 *$ \\
Weight per fruit & $0.89 \mathrm{~ns}$ & $3.96 *$ & $0.96 \mathrm{~ns}$ \\
Fresh fruit weight & $0.39 \mathrm{~ns}$ & $2.37 \mathrm{~ns}$ & $1.37 \mathrm{~ns}$ \\
\hline
\end{tabular}

ns = non significance; $*$ = significantly difference 
On the other hand, widest canopy is reached when Siam Weed is applied 2 weeks before planting date as compared to the other compost application, then continue declining until application of 4 weeks before planting date. This indicates that nutrient released by Siam Weed compost applied 2 weeks before planting date is available at the right time for chili pepper growth. The decrease in canopy width when weed compost applied before 2 weeks of planting date might be associated with the loss of nutrient due to immobilization and leaching.

TABLE II

CANOPY WIDTH (CW) AND LENGTH OF CHILI FRUIT (FL) AS AFFECTED BY INTERACTION OF COMPOST TYPES AND TIMES OF APPLICATION.

\begin{tabular}{|l|c|c|}
\hline \multicolumn{1}{|c|}{ Treatment Combination } & CW $(\mathrm{cm})$ & FL $(\mathrm{cm})$ \\
\hline Wedelia compost at planting date & $64.2 \mathrm{ab}$ & $10.8 \mathrm{a}$ \\
Wedelia 1 week before planting date & $59.0 \mathrm{ab}$ & $10.7 \mathrm{a}$ \\
Wedelia 2 week before planting date & $54.2 \mathrm{~b}$ & $10.7 \mathrm{a}$ \\
Wedelia 3 week before planting date & $52.4 \mathrm{~b}$ & $8.6 \mathrm{ab}$ \\
Wedelia 4 week before planting date & $40.4 \mathrm{~b}$ & $11.1 \mathrm{a}$ \\
Siam weed compost at planting date & $61.6 \mathrm{~b}$ & $7.2 \mathrm{ab}$ \\
Siam weed 1 week before planting date & $56.8 \mathrm{ab}$ & $11.9 \mathrm{a}$ \\
Siam weed 2 week before planting date & $81.2 \mathrm{a}$ & $10.1 \mathrm{ab}$ \\
Siam weed 3 week before planting date & $59.0 \mathrm{~b}$ & $7.0 \mathrm{~b}$ \\
Siam weed 4 week before planting date & $46.4 \mathrm{~b}$ & $9.9 \mathrm{ab}$ \\
\hline
\end{tabular}

Means followed by different letter within column are significantly different (DMRT 5\%); CW = Canopy Width; FL = Fruit Length

Table 2 also shows that Siam weed compost applied 2 weeks before planting provides almost $50 \%$ wider canopy than that of Wedelia compost. However, other times of either Wedelia or Siam weed compost application do not provide significant differences on canopy width. The widest canopy of chili pepper $(81.2 \mathrm{~cm})$ is reached when the plant was fertilized with Siam weed compost applied 2 weeks before planting date while the narrowest canopy $(40.4 \mathrm{~cm})$ is achieved when the plant is fertilized with Wedelia compost applied 4 weeks before planting date. This result is in the range of canopy width of chili pepper as reported by [17].

Similar trend is observed on fruit length of chili pepper. Fruit length is decreasing when Wedelia compost is applied before planting date as seen in Table 2. However, chili pepper fertilized with Siam weed compost a week before planting results in longest fruit of chili pepper. This indicates that Siam weed compost is applied better at 1-2 weeks before planting date while Wedelia compost is applied at planting date. This is related to lower $\mathrm{C} / \mathrm{N}$ ratio of Wedelia compost as compared that of Siam weed compost, resulting in faster decay of Wedelia compost.

\section{Effect of Weed Composts on Growth and Yield of Chili Pepper}

Comparison on types of weed composts shows that most of growth and yield component variables are not affected by types of compost. However, chili pepper fertilized with Wedelia compost produces significantly taller plant $(80.84$ $\mathrm{cm})$ than that fertilized with Siam Weed compost $(66.28 \mathrm{~cm})$. This is followed by higher canopy dry weight per plant (7.51 g) of chili pepper fertilized with Wedelia compost in comparison to that Siam weed compost (5.72 g). In addition, the experiment also shows that dichotomous height, flowering time, stem diameter, canopy width, harvesting time, root dry weight per plant, fruit diameter, fruit length, fresh fruit weight per plant, and weight per fruit tend to be higher when chili pepper is fertilized with Wedelia compost as compared to Siam weed compost. It might be related to nutrient composition of Wedelia and Siam weed composts. Wedelia compost contains organic carbon, nitrogen, phosphorous and potassium as much as $48.2 \%, 3.2 \%, 0.38 \%$, and $4.33 \%$ respectively while Siam weed compost contains organic carbon, nitrogen, phosphorous and potassium as much as $43.6 \%, 2.65 \%, 0.53 \%$, and $1.90 \%$ respectively (compost analysis). Wedelia compost is decomposed quite rapidly [11] and upon decomposition of Wedelia compost will provide higher availability of nitrogen and potassium even though lower availability of phosphorus as compared to Siam weed compost. Greenhouse experiment conducted by [18] revealed that mustard fertilized with Wedelia compost resulted in significantly higher leaf length, canopy fresh weight, root fresh weight, canopy dry weight, as well as root dry weight as compared to that of fertilized with Siam weed compost.

\section{Growth and Yield of Chili Pepper as Affected by Times of Application}

Table 3 and 4 shows that growth variables do not influenced by times of application.

TABLE III

Plant HeIGHT (PH), DICHOTOMOUS HEIGHT (DH) AND STEM DIAMETER (SD) OF CHILI PEPPER AS AFFECTED BY TIMES OF APPLICATION.

\begin{tabular}{|l|c|c|c|}
\hline Times of Application & PH $(\mathrm{cm})$ & DH $(\mathrm{cm})$ & SD $(\mathrm{mm})$ \\
\hline At Planting date & 77.00 & 38.21 & 0.77 \\
1 week before planting & 89.18 & 37.46 & 0.93 \\
2 week before planting & 63.10 & 34.34 & 0.72 \\
3 week before planting & 58.00 & 31.68 & 0.62 \\
4 week before planting & 71.10 & 34.21 & 0.80 \\
\hline
\end{tabular}

However, weed compost applied one week before planting tends to produce better growth performance of chili pepper than other times of compost application.

TABLE IV

CANOPY WIDTH (CW), CANOPY DRY WEIGHT (CDW) AND ROOT DRY WEIGHT (RDW) OF CHILI PEPPER AS AFFECTED BY TIMES OF APPLICATION.

\begin{tabular}{|l|c|c|c|}
\hline Times of Application & CW $(\mathrm{cm})$ & CDW $(\mathrm{g})$ & RDW $(\mathrm{g})$ \\
\hline At Planting date & 57.90 & 6.88 & 4.37 \\
1 week before planting & 67.70 & 6.84 & 6.57 \\
2 week before planting & 45.70 & 6.68 & 4.22 \\
3 week before planting & 43.40 & 6.92 & 4.24 \\
4 week before planting & 62.90 & 5.74 & 4.88 \\
\hline
\end{tabular}

As seen in Table 3 and 4, it is suggested that plant height, dichotomous height, stem diameter, canopy width and root dry weight of chili pepper fertilized with weed compost one week before planting date are among the best in comparison to the other times of compost application. Compost application 1-2 weeks before planting will offer sufficient time to decompose. Upon the decomposition, compost will provide nutrient for plant growth as reported by [7].

Similar trend is detected on the yield component variables of chili pepper. Flowering time and weight per chili pepper 
fruit is significantly influenced by times of compost application (Table 5 and 6).

TABLE V

FLOWERING TIME (FT), WEIGHT PER FRUIT (WF), HARVESTING TIME (HT) OF CHILI PEPPER AS AFFECTED BY TIMES OF APPLICATION.

\begin{tabular}{|l|c|c|c|}
\hline Times of Application & FT (DAT) & WF (g) & HT (DAT) \\
\hline At Planting Date & $26 \mathrm{~b}$ & $3.20 \mathrm{a}$ & 66 \\
1 week before planting & $37 \mathrm{a}$ & $3.50 \mathrm{a}$ & 77 \\
2 week before planting & $28 \mathrm{ab}$ & $2.05 \mathrm{~b}$ & 68 \\
3 week before planting & $27 \mathrm{~b}$ & $3.05 \mathrm{ab}$ & 67 \\
4 week before planting & $30 \mathrm{ab}$ & $2.22 \mathrm{~b}$ & 70 \\
\hline
\end{tabular}

Even though flowering time is significantly longer, one week of compost application results in significant higher weight of chili fruit. In addition, fruit length and fresh fruit weight per plant tend to be highest when chili pepper fertilized one week before planting as compared to other times of compost application.

TABLE VI

FRUIT DIAMETER (FD), FRUIT LENGTH (FL), FRESH FRUIT WEIGHT (FFW) OF CHILI PEPPER AS AFFECTED BY TIMES OF APPLICATION.

\begin{tabular}{|l|c|c|c|}
\hline Times of Application & FD $(\mathrm{mm})$ & FL $(\mathrm{cm})$ & FFW $(\mathrm{g})$ \\
\hline At Planting Date & 0.66 & 10.60 & 7.77 \\
1 week before planting & 0.60 & 11.34 & 9.39 \\
2 week before planting & 0.56 & 10.45 & 7.34 \\
3 week before planting & 0.46 & 8.31 & 4.53 \\
4 week before planting & 0.52 & 10.30 & 7.84 \\
\hline
\end{tabular}

\section{CONCLUSIONS}

Siam weed compost applied two weeks before planting results in plant canopy wider than Wedelia compost. However, Wedelia compost applied at planting date results in longer chili pepper as compared to Siam weed compost. Wedelia compost produces higher plant height and root dry weight as compared to Siam weed compost.

\section{REFERENCES}

[1] Majid, A. 1998. Peningkatan efisiensi pemupukan fosfat dan hasil kedelai dengan menekan adsorpsi $\mathrm{P}$ maksimum akibat pemberian ameliuron pada Ultisol Jambi. Doctor Diss. Universitas Padjadjaran. Bandung (unpublished).

[2] Susanto, R. 2005. Dasar-Dasar Ilmu Tanah. Kaninsus. Yogyakarta
[3] Spark D. 2003. Environmental Soil Chemistry. $2^{\text {nd }}$ edition. Acvademic Press. New York.

[4] Lehmann J., J. Kinyangi, and D. Solomon. 2007. Organic matter stabilization in soil microaggregates: implications from spatial heterogeneity of organic carbon contents and carbon forms. Biogeochemistry 85:45-57.

[5] Clark, M. S., W. R. Horwath, C. Shennan, and K. M. Scow. 1998. Changes in Soil Chemical Properties Resulting from Organic and Low-Input Farming Practices Agron. J. 90:662-671 (1998).

[6] Marriott, E. and M.M. Wander. 2006. Total and labile soil organic matter in organic and conventional farming systems. Soil Science Society of America Journal 70:950-959

[7] Reganold J. P., P. K. Andrews, J. R. Reeve, L. Carpenter-Boggs, C. W.Schadt, J. R. Alldredge, C. F. Ross, N. M. Davies, and J. Zhou. 2010. Fruit and soil quality of organic and conventional strawberry

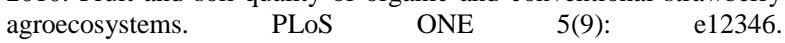
doi:10.1371/journal.pone.0012346.

[8] Maftu'ah, E., S. Asikin, and A. Najib. 2005. Potensi gulma Cromolaena odorata dan Agerathum conyzoides sebagai sumber pupuk $\mathrm{N}$ dan $\mathrm{P}$ untuk menuju sistem pertanian organik. Proc. Konferensi Nasional XVII Himpunan Ilmu Gulma Indonesia. Yogyakarta 20-21 Juli 2005.

[9] Simanungkalit, R. D. M. 2006. Prospek Pupuk Organik dan Hayati dalam Pupuk Organik dan Pupuk Hayati (Organic Fertilizer and Biofertilizer). Balai Besar Litbang Sumber Daya Lahan Pertanian, Bogor.

[10] Aini, N. S. Soeprapto dan T. H. Gultom. 1999. Pengaruh dosis dan waktu aplikasi bokasi terhadap pertumbuhan dan hasil tanaman strowberry (Fragaria vesca L). Jurnal Ilmiah Habitat 10 (106 ). 1416.

[11] Handayani, I. P. Prawito. dan Z. Muktamar. 2002. Lahan paska deforestasi di Bengkulu, Sumatra ; II. Kajian Peranan Vegetasi Invasi. J. Ilmu Pertanian IV (1) : 10- 17.

[12] Handayani, I.P. dan P. Prawito. 2006. Tumbuhan Perintis Pemulihan Lahan Kritis. Penerbit KEHATI. Bengkulu.

[13] Dwi, M.S. 2003. Distribusi mikroorganisme dan bahan organik tanah pada barbagai tipe tanah. Skripsi . Fakultas pertanian. Universitas Bengkulu. (unpublished).

[14] Antoni, H. 2005. Perubahan karakteristik tanah marginal akibat penanaman lima jenis vegetasi pionir: Percobaan rumah kaca. Skripsi. Fakultas Pertanian. Universitas Bengkulu. (unpublished).

[15] Hadinata, R. 2005. Kajian kemampuan vegetasi pionir dan pupuk organik dalam memperbaiki sifat-sifat tanah bekas alang - alang. Skripsi. Fakultas pertanian. Universitas Bengkulu. (unpublished).

[16] Daryono, H. dan Hamzah, Z. 1997. Studi mengenai gulma Eupatorium Odoratum yang terdapat di hutan Tektona gradis $\mathrm{L}$. Lembaga Penelitian Hutan Bogor. Bogor.

[17] Febriansyah, 2013. Karakterisasi variabel kualitatif dan kuantitatif cabai hibrida hasil persilangan dialel. Skripsi. Universitas Bengkulu. (unpublished).

[18] Setyowati N., U. Nurjanah, and D. Haryanti 2008. Gulma Tusuk Konde (Wedelia trilobata) dan kirinyu (Chlomolaena odorata) sebagaipupuk organik pada sawi (Brassica chinensis L.) Akta Agrosia 11(1): 47-56 